\title{
Globalization and its Impact on Cooperatives - A Case of Oromiya Regional State, Ethiopia
}

\author{
Karunakara Rao $\mathbf{R}^{*}$ and Asfaw Temesgen
}

\author{
Department of Cooperative, College of Business and Economics, Wollega University, P.O. Box: 395, \\ Nekemte, Ethiopia
}

\begin{tabular}{|c|c|}
\hline Abstract & Article Information \\
\hline $\begin{array}{l}\text { Present research was designed to find the contribution of globalization to cooperative } \\
\text { organizations in Oromiya region, Ethiopia. } 152 \text { employees from Oromiya regional } \\
\text { cooperative promotion office working in cooperative organizations in the } 17 \text { zones of } \\
\text { Oromiya region joined Wollega University for their upgrading education are selected as } \\
\text { the sample, and Questionnaire method is used to collect the data from the sample } \\
\text { respondents. Questionnaire contains demographic profile of the respondents, respondents } \\
\text { general views on globalization ( } 23 \text { statements on } 5 \text { point Likert scale), cooperative } \\
\text { organization profile and respondent opinions on impact of globalization on cooperative } \\
\text { organizations ( } 17 \text { statements on } 5 \text { point Likert scale). The results of the research revealed } \\
\text { that globalization in Ethiopia positively benefited the country with increased employment } \\
\text { opportunities, improvement in infrastructure facilities, flow of goods from all over the world, } \\
\text { attracting foreign investments, dissemination of education and technology, upgrading in } \\
\text { living conditions and standard of living and negatively impacted with environmental } \\
\text { degradation, deforestation, cultural change, corruption, inequalities, over dependency on } \\
\text { other countries. Globalization to the Ethiopian cooperatives positively benefited with } \\
\text { adoption of global cooperative principles, global standards, new technologies and } \\
\text { methods, attracting investments and donations from the external world and qualitative } \\
\text { education and training programs and negatively impacted as competition from the } \\
\text { multinationals, and neglected by the own government. } \\
\text { Copyright@2014 STAR Journal. All Rights Reserved. }\end{array}$ & $\begin{array}{l}\text { Article History: } \\
\text { Received : 31-01-2014 } \\
\text { Revised : 20-03-2014 } \\
\text { Accepted : 22-03-2014 } \\
\text { Keywords: } \\
\text { Globalization } \\
\text { Globalization effects } \\
\text { Oromiya } \\
\text { Wollega University } \\
\text { Ethiopia } \\
\text { Cooperatives } \\
\text { *Corresponding Author: } \\
\text { Karunakara Rao R } \\
\text { E-mail: } \\
\text { karunakararao@hotmail.com }\end{array}$ \\
\hline
\end{tabular}

\section{INTRODUCTION}

Globalization is growing economic interdependence of countries worldwide through increasing volume and variety of cross-border transactions in goods and services, free international capital flows, and more rapid and widespread diffusion of technology (IMF, 2008). Globalization may benefits the countries with increased productivity, availability of goods for cheaper prices, employment creation due to new start-ups from the foreign capital and innovative ideas due to free flow of information. At the same time it will give some negative affects to the countries, by affecting domestic industry, widening the gap between rich and poor, monopoly of foreign companies, environmental degradation and cultural transition etc (Karunakara Rao, 2013).

Ethiopia is also waved with globalization since its modern inception during 90s. Ethiopia is second most populous nation in Africa, with 83 million people with 70 ethnic groups who speak more than 80 languages. Ethiopia's economy is based on agriculture, which accounts for $46 \%$ of GDP and $85 \%$ of total employment. The per capita income is lowest in the world. Coffee has been a major export crop. The banking, insurance, and micro-credit industries are restricted to domestic investors, but Ethiopia has attracted significant foreign investment in textiles, leather, commercial agriculture and manufacturing. Ethiopia's economy continues on its stateled Growth and Transformation Plan under its new leadership after Prime Minister Meles's death (Karunakara Rao, 2013).

Wegenie (1989) studied the performance of cooperatives at micro and macro level and the problems of development of cooperatives in Ethiopia by using linear programming model. Tanguy Bernard et al. (2006) identified the conditions under which Rural Producers Organizations engaged in cereal marketing successfully promote smallholder commercialization and to determine how the benefits are distributed. David J. Spielman (2007) examined how cooperatives in Ethiopia facilitate commercial linkages between smallholders and markets, manage scarce natural resources at the community level, and strengthen local governance systems and the articulation of community voice. Tanguy Bernard et al. (2007) examined the impact of marketing cooperatives on smallholder commercialization of cereals using detailed household data in rural Ethiopia. Yuka Kodama (2009) examined fair trade coffee and its impacts on farmers in by examining the role of coffee cooperatives in Ethiopia. 
Karunakara Rao and Asfaw Temesgen

Bezabih Emana (2009) reviewed the history and development of cooperatives in Ethiopia since ancient times to modern times further the functionality of cooperatives is constrained by shortages in skilled human resources, shortage of capital and limited access to credit. Woldegebrial Zeweld et al. (2010) explored the roles that agricultural cooperatives to achieve women empowerment, generating employment, and environment rehabilitation. Gian Nicola Francesconi et al. (2010) examined the impact of cooperative membership on commercialization and stated selective inclusion of marketing cooperatives in the commodity exchange system has the potential to simultaneously reduce the rural poverty and maximize agro-commodity commercialization in Ethiopia. Maria F Rodrigoy (2012) analyzed how producer cooperatives may benefit households in rural environments. Ruerd Ruben et.al (2012) studied performance of agrarian (coffee) cooperatives under the perspectives of Social Capital and Governance. Gashaw Tadesse et al. (2012) studied the impact of agricultural cooperatives on smallholders' technical efficiency. Kifle Tesfamariam Sebhatu (2012) identified income, education level, training, years of stay in the cooperatives, marital status and asset ownership are statistically significant at all levels and have positive impact on women empowerment. Very few empirical studies are conducted on Ethiopian cooperatives, and no studies are available on globalization and its impact on Ethiopian cooperatives. The focus in this paper is on the concept of "globalization" as applied to the Ethiopian economy particularly to cooperative organizations. Specifically, this paper aimed to present brief history and present status of Ethiopian cooperatives, to review past studies on Ethiopian cooperatives and to present opinions of cooperative employees regarding globalization.

\section{History and Present Status of Ethiopian Cooperatives}

Traditional cooperatives associations existed in Ethiopian society in general and Oromiya state in particular centuries ago in the form of lqub, Idir debbo. lqub is an association of people having common objectives of mobilizing resources, especially finance, and distributing it to members on rotating basis. Idir is an association of people that have the objective of providing social and economic insurance for the members in the events of death, accident, damages to property, among others. In the case of funeral, Idir serves as funeral insurance where community members elect their leaders; contribute resources either in kind or in cash and support the mourning member. Debbo is an informal association in which the members are cooperate each other in some activities which could not be possible for individual action like in case of harvesting of crop (Bezabih, 2009). Modern form of cooperatives started in Ethiopia during the ruling era of Emperor Haile Selassie. In 1960 he announced the first legislative called "Farm Workers Cooperatives Decree" was declared as Decree No.44/1960 with the objective of acceleration and development of agriculture in the Ethiopian economy (Veerakumaran, 2007). Decree No.44/1960 had no full version of cooperative proclamation and unsuccessful because of limited to agricultural cooperatives with very limited government support, lack of supporting laws and land tenure system. As a result Cooperative society Proclamation No.241/1966 was to come to effective with consideration of previous Decree's short comings (Veerakumaran, 2007). By this proclamation Ethiopian cooperatives
Sci. Technol. Arts Res. J., Jan-March 2014, 3(1): 162-171

adopted cooperative principles to achieve social justice and better business by 1974 there were about 149 cooperatives (Teigist, 2008).

In 1974, a military junta, the Derg, deposed Emperor Haile Selassie (who had ruled since 1930) and established a socialist state. The Cooperative Societies Proclamation No. 138/1978 was issued to achieve selfreliance, increased and cooperative controlled production, to accumulate capital, and to mobilize the resources for sustainable economic development in the country. During Derg regime cooperatives were among the victims. Cooperatives were faded with organizational, operational, leadership as well as production and distribution problems. During fall of Derg regime (May 1991) multipurpose cooperatives are looted and dismantled even by their own members. Cooperative values and principles were violated by the cooperative movement of that period; there were some positive contributions to the cooperative development of Ethiopia. During this period the country witnessed expansion and promotion of different types of cooperatives. Introduction of distribution of consumer goods and extending agricultural credits (inputs, oxen, tractors and machinery etc.) through cooperatives. The establishment of cooperative training center (Ardaita), government support to investment and infrastructural facilities, provision of domestic and international training.

After the downfall of the Derg regime, there was a gap between 1991-1995 in the cooperative movement of Ethiopia. This gap was created due to the fact that the government's attention was mainly drawn towards stabilizing, bringing peace and creating administration organs. Agricultural Cooperative Societies Proclamation No.85/1994 was introduced to serve only agricultural cooperatives, with an aim to achieve improved living conditions to its members by increasing production and productivity by using modern technologies, to satisfy social and community needs of the members and to promote culture of the members by teaching and training.

The government has taken serious measures after 1996. The measures include, organizing and reorganizing different types of agricultural cooperative societies and establishing cooperative promotion bureaus/ offices in regions. In the Federal government the cooperative promotion desk under the Prime Minister office has been also established. A proclamation No. 147/ 1998 to provide for the establishment of cooperative societies had been also declared by the Federal Government to bring all types of cooperative societies under one umbrella. Proclamation No.147/1998 was an important milestone for Ethiopian cooperatives as full version based on all cooperative principles in the free market economic system with varieties of cooperatives. This proclamation aimed to achieve self-reliance to its members, to improve living standards of its members, to collectively protect, withstand and solve economic problems, to expand the mechanism by which technical knowledge could be put in to practice, to develop and promote savings and credit services, and to develop the social and economic culture of the members through education and training.

Later on the Federal Cooperative Commission (the currently Federal Cooperative Agency) based on proclamation no. 274 / 2002 was established in 2002. More over to correct the short-comings in the 
Karunakara Rao and Asfaw Temesgen

proclamation 147/1998 amendment 402/ 2002 and regulation number 106/2002, proclamation-No. 402/2004 became important instrumental documents in the cooperative movement of the country. The latest proclamations let cooperative free organization as it includes international cooperative principles and some privilege from the government. Government established cooperative supporting institution, cooperative promotion bureau from federal to woreda level and launching cooperative training from vocational education up to master's degree level who supporting cooperative promotion and extension. All these serve as cooperative development opportunity.

Currently, cooperative societies in Ethiopia expanded horizontally and vertically in different sector of economy as it can be seen from the table 1, and in the same manner cooperatives engaged in diversified business to serve the members, mostly the disadvantaged groups of people. Hence cooperatives in Ethiopia take part in local and national market and enter into international market for scaling up the business and services. The present study focuses on globalization and its impact on cooperative organizations in the Oromiya Region, Ethiopia.

Table 1: Expansion of cooperatives in Ethiopia and Oromiya region.

\begin{tabular}{|c|c|c|c|}
\hline No & Category of Cooperative & Ethiopia & $\begin{array}{c}\text { Oromiya } \\
\text { Region }\end{array}$ \\
\hline \multicolumn{4}{|c|}{ Primary Cooperatives } \\
\hline 1 & Agricultural cooperative & 9,854 & 5,387 \\
\hline 2 & Saving and credit cooperative & 7,077 & 3,579 \\
\hline \multirow[t]{2}{*}{3} & Other cooperative* & 20,316 & 2,355 \\
\hline & Total & 37,247 & 11,321 \\
\hline \multicolumn{4}{|c|}{ Cooperative Unions } \\
\hline 1 & Agricultural cooperative & 156 & 99 \\
\hline 2 & Saving and credit cooperative & 64 & 27 \\
\hline \multirow[t]{2}{*}{3} & Other cooperative & 25 & 12 \\
\hline & Total & 245 & 138 \\
\hline \multicolumn{4}{|c|}{ Cooperative Federations } \\
\hline 1 & Agricultural & $3^{* *}$ & 1 \\
\hline \multirow[t]{2}{*}{2} & Mining & 1 & 1 \\
\hline & Total & 4 & 2 \\
\hline
\end{tabular}

Cooperative League (Not yet established)

Source: Oromiya Region Cooperative Promotion Agency

*other cooperative includes consumer, mining, rural electric supply etc.

${ }^{* *}$ other 2 agricultural cooperative federations are located at South Ethiopia and Tigray regions.

\section{MATERIALS AND METHODS}

\section{Sample}

The populations for the present study are employees in cooperative organizations in the Oromiya region, Ethiopia. The samples selected for the present study are employees of Oromiya regional cooperative promotion office working in cooperative organizations from 17 administrative zones of Oromiya region out of its 18 zones. The selected samples are joined in Wollega University for upgrading their education. Total 185 cooperative employees are pursuing two courses i.e. Cooperative Accounting and Auditing and Cooperative Business Management. Questionnaire were distributed to all 185 members and got response from 152 members. The remaining 33 respondents were not interested to participate in the study.
Sci. Technol. Arts Res. J., Jan-March 2014, 3(1): 162-171

\section{Survey Instrument}

The survey questionnaire has 4 parts. $1^{\text {st }}$ part was about respondent demographic profile includes sex, age, designation, experience, monthly income and motive for present education. $2^{\text {nd }}$ part was about general views on globalization which includes 23 statements on both positive and negative effects of globalization on Ethiopian context on 5 point Likert scale. $3^{\text {rd }}$ part was about profile of cooperative organizations which includes the type of cooperative, established date, member strength, capital and location and $4^{\text {th }}$ part was about the positive and negative effects to cooperatives include 17 statements which was related to Ethiopian cooperatives in relation with globalization on 5 point Likert scale.

\section{Statistical Analysis}

Primary data was analyzed by using SPSS for Windows version 21.0. Percentages, Mean, Standard Deviations (SD) and linear regression were used to interpret the data.

\section{RESULTS AND DISCUSSION}

Table 2 presents the Reliability analysis for the questionnaire. The obtained final Cronbach's Alpha score for all listed items is 0.557 , which indicated that data has satisfactory internal consistency.

Table 2: Reliability Statistics.

\begin{tabular}{cc}
\hline Cronbach's Alpha & Number of Items \\
\hline 0.557 & 42 \\
\hline
\end{tabular}

Table 3 presents demographic profile of the respondents. 84.2 percent are Male and 15.8 percent are female. The mean for the respondents' sex is 1.1579 , and the standard deviation is 0.36585 . 9.2 percent of the respondents are in the age group of 18-22 years, 65.8 percent of the respondents are in the age group of 23-27 years, 17.1 percent of the respondents are in the age group of 28-32 years, 2.6 percent of the respondents in the age group of 33-40 percent and 5.3 percent of the respondents in the age group of 40-50 years. The mean age of the respondents is 2.2895 and standard deviation for the age of the respondents is 0.87369 . 35.5 percent of the respondents are Accountants and 64.5 percent of the respondents are Organizers/mentors in the cooperative organizations. 68.4 percent of the respondents are working from 3-5 years, 23.7 percent of the respondents are working from 6-8 years, 2 percent of the respondents are working from 9-10 years, and 5.9 percent of the respondents working from more than 10 years. The mean for the experience of the respondents is 1.4539 and standard deviation is 0.80428 . 1.3 percent of the respondents are getting less than 1000 ETB as their monthly income, 43 percent of the respondents are getting 1001-1500 ETB as their monthly income, 42.8 percent of the respondents are getting 1501-2000 ETB as their monthly income, and 7.9 percent of the respondents are getting above 2000 ETB as their monthly income. The mean income for the respondents is 2.5724 . 24.3 percent of the respondents are upgrading their education to acquire knowledge, 53.9 percent of the respondents are to get promotion and 21.7 percent are to improve their educational qualification. The mean opinion for the motive for present education is 1.9737 and the standard deviation is 0.68035 . 
Table 3: Respondents demographic profile.

\begin{tabular}{|c|c|c|c|c|c|}
\hline & & Frequency & Percent & Mean & SD \\
\hline \multirow{2}{*}{ Sex } & Male & 128 & 84.2 & \multirow{2}{*}{1.1579} & \multirow{2}{*}{0.3659} \\
\hline & Female & 24 & 15.8 & & \\
\hline \multirow{17}{*}{$\begin{array}{l}\text { Working } \\
\text { Region }\end{array}$} & West Wollega & 13 & 8.6 & \multirow{17}{*}{8.8355} & \multirow{17}{*}{4.9319} \\
\hline & East Wollega & 7 & 4.6 & & \\
\hline & Horogudru Wollega & 3 & 2.0 & & \\
\hline & Ilu Aba Bora & 12 & 7.9 & & \\
\hline & Jimma & 13 & 8.6 & & \\
\hline & West Shewa & 10 & 6.6 & & \\
\hline & North Shewa & 8 & 5.3 & & \\
\hline & East Shewa & 8 & 5.3 & & \\
\hline & Arsi & 8 & 5.3 & & \\
\hline & West Arsi & 6 & 3.9 & & \\
\hline & West Hararge & 11 & 7.2 & & \\
\hline & East Hararge & 9 & 5.9 & & \\
\hline & Bale & 13 & 8.6 & & \\
\hline & Borena & 9 & 5.9 & & \\
\hline & South West Shewa & 6 & 3.9 & & \\
\hline & Guji & 10 & 6.6 & & \\
\hline & Kellam Wollega & 6 & 3.9 & & \\
\hline \multirow{5}{*}{ Age } & $18-22$ years & 14 & 9.2 & \multirow{5}{*}{2.2895} & \multirow{5}{*}{0.8737} \\
\hline & $23-27$ years & 100 & 65.8 & & \\
\hline & $28-32$ years & 26 & 17.1 & & \\
\hline & $33-40$ years & 4 & 2.6 & & \\
\hline & $40-50$ years & 8 & 5.3 & & \\
\hline \multirow{2}{*}{ Designation } & Accountant & 54 & 35.5 & \multirow{2}{*}{1.6447} & \multirow{2}{*}{0.4802} \\
\hline & Organizer/Mentor & 98 & 64.5 & & \\
\hline \multirow{4}{*}{ Experience } & $3-5$ years & 104 & 68.4 & \multirow{4}{*}{1.4539} & \multirow{4}{*}{0.8043} \\
\hline & $6-8$ years & 36 & 23.7 & & \\
\hline & $9-10$ years & 3 & 2.0 & & \\
\hline & Above 10 years & 9 & 5.9 & & \\
\hline \multirow{4}{*}{$\begin{array}{l}\text { Monthly } \\
\text { Income }\end{array}$} & Less than $1000 \mathrm{ETB}$ & 2 & 1.3 & \multirow{4}{*}{2.5724} & \multirow{4}{*}{0.6571} \\
\hline & 1001-1500 ETB & 73 & 48.0 & & \\
\hline & 1501-2000 ETB & 65 & 42.8 & & \\
\hline & Above 2000 ETB & 12 & 7.9 & & \\
\hline \multirow{3}{*}{$\begin{array}{l}\text { Motive for } \\
\text { Present } \\
\text { Education }\end{array}$} & To acquire Knowledge & 37 & 24.3 & \multirow{3}{*}{1.9737} & \multirow{3}{*}{0.6804} \\
\hline & To get Promotion & 82 & 53.9 & & \\
\hline & $\begin{array}{l}\text { To improve educational } \\
\text { qualification }\end{array}$ & 33 & 21.7 & & \\
\hline
\end{tabular}

Table 4 presents respondents general views on

and the standard deviations to 23 positive and negative globalization; it presents the frequencies, mean opinions statements on globalization and its impact on Ethiopia.

Table 4: Respondents general views on globalizational impact on Ethiopia.

\begin{tabular}{|c|c|c|c|c|c|}
\hline & & Frequency & Percent & Mean & SD \\
\hline \multirow{2}{*}{ Awareness about globalization } & Yes & 152 & 100 & \multirow{2}{*}{1.0000} & \multirow{2}{*}{0.0000} \\
\hline & No & 0 & 0 & & \\
\hline \multirow{4}{*}{ Necessity of globalization to Ethiopia } & Very important & 40 & 26.3 & \multirow{4}{*}{1.9868} & \multirow{4}{*}{0.7719} \\
\hline & Important & 80 & 52.6 & & \\
\hline & Neutral & 26 & 17.1 & & \\
\hline & Unimportant & 6 & 3.9 & & \\
\hline \multirow{4}{*}{$\begin{array}{l}\text { Important organizations for the growth of } \\
\text { Ethiopia }\end{array}$} & Cooperative Organizations & 56 & 36.8 & \multirow{4}{*}{1.9803} & \multirow{4}{*}{0.9998} \\
\hline & Public Enterprises & 64 & 42.1 & & \\
\hline & Private Organizations & 11 & 7.2 & & \\
\hline & Multinational Corporations & 21 & 13.8 & & \\
\hline \multirow{5}{*}{$\begin{array}{l}\text { Globalization helps to identify natural } \\
\text { resources in Ethiopia }\end{array}$} & Strongly Agree & 32 & 21.1 & \multirow{5}{*}{2.5132} & \multirow{5}{*}{1.1679} \\
\hline & Agree & 50 & 32.9 & & \\
\hline & Neutral & 42 & 27.6 & & \\
\hline & Disagree & 16 & 10.5 & & \\
\hline & Strongly Disagree & 12 & 7.9 & & \\
\hline \multirow{5}{*}{$\begin{array}{l}\text { Globalization provided investments to } \\
\text { different sectors in Ethiopia }\end{array}$} & Strongly Agree & 65 & 42.8 & \multirow{5}{*}{2.0197} & \multirow{5}{*}{1.0764} \\
\hline & Agree & 36 & 23.7 & & \\
\hline & Neutral & 38 & 25.0 & & \\
\hline & Disagree & 9 & 5.9 & & \\
\hline & Strongly Disagree & 4 & 2.6 & & \\
\hline
\end{tabular}




\begin{tabular}{|c|c|c|c|c|c|}
\hline \multirow{3}{*}{$\begin{array}{l}\text { Globalization in Ethiopia helped to receive } \\
\text { qualitative education in the Ethiopia }\end{array}$} & Strongly Agree & 90 & 59.2 & \multirow{3}{*}{1.5263} & \multirow{3}{*}{0.6996} \\
\hline & Agree & 44 & 28.9 & & \\
\hline & Neutral & 18 & 11.8 & & \\
\hline \multirow{3}{*}{$\begin{array}{l}\text { Globalization in Ethiopia helped to receive } \\
\text { advanced technical know-how in the } \\
\text { Ethiopia }\end{array}$} & Strongly Agree & 65 & 42.8 & \multirow{3}{*}{1.6711} & \multirow{3}{*}{0.6488} \\
\hline & Agree & 72 & 47.4 & & \\
\hline & Neutral & 15 & 9.9 & & \\
\hline \multirow{3}{*}{$\begin{array}{l}\text { Globalization provided Ethiopia with good } \\
\text { infrastructural facilities }\end{array}$} & Strongly Agree & 44 & 28.9 & \multirow{3}{*}{1.8684} & \multirow{3}{*}{0.65795} \\
\hline & Agree & 84 & 55.3 & & \\
\hline & Neutral & 24 & 15.8 & & \\
\hline \multirow{4}{*}{$\begin{array}{l}\text { Globalization in Ethiopia helped to improve } \\
\text { standard of living in the country }\end{array}$} & Strongly Agree & 38 & 25.0 & \multirow{4}{*}{2.2566} & \multirow{4}{*}{0.8727} \\
\hline & Agree & 42 & 27.6 & & \\
\hline & Neutral & 67 & 44.1 & & \\
\hline & Disagree & 5 & 3.3 & & \\
\hline \multirow{4}{*}{$\begin{array}{l}\text { Globalization in Ethiopia helped to raise in } \\
\text { income levels of the people }\end{array}$} & Strongly Agree & 31 & 20.4 & & \\
\hline & Agree & 81 & 53.3 & 21110 & \\
\hline & Neutral & 32 & 21.1 & 2.1118 & 0.1852 \\
\hline & Disagree & 8 & 5.3 & & \\
\hline & Strongly Agree & 19 & 12.5 & & \\
\hline & Agree & 79 & 52.0 & & \\
\hline $\begin{array}{l}\text { Globalization in Ethıopla enhanced } \\
\text { employment opportunities in the country }\end{array}$ & Neutral & 41 & 27.0 & 2.3355 & 0.8531 \\
\hline & Disagree & 10 & 6.6 & & \\
\hline & Strongly Disagree & 3 & 2.0 & & \\
\hline & Strongly Agree & 27 & 17.8 & & \\
\hline & Agree & 72 & 47.4 & & \\
\hline Giobalization helped Ethiopia with access & Neutral & 48 & 31.6 & 2.2171 & 0.8049 \\
\hline & Disagree & 3 & 2.0 & & \\
\hline & Strongly Disagree & 2 & 1.3 & & \\
\hline & Strongly Agree & 97 & 63.8 & & \\
\hline & Agree & 39 & 25.7 & & \\
\hline Globallzation nelped Ethiopla with rlow of & Neutral & 11 & 7.2 & 1.5066 & 0.7973 \\
\hline & Disagree & 4 & 2.6 & & \\
\hline & Strongly Disagree & 1 & .7 & & \\
\hline & Strongly Agree & 71 & 46.7 & & \\
\hline Globalization helped Ethiopia to sell & Agree & 58 & 38.2 & & \\
\hline Ethiopian products across the countries & Neutral & 20 & 13.2 & 1.7039 & 0.7706 \\
\hline & Disagree & 3 & 2.0 & & \\
\hline & Strongly Agree & 49 & 32.2 & & \\
\hline & Agree & 62 & 40.8 & & \\
\hline Gilobalizatıon aftected household and small & Neutral & 35 & 23.0 & 2.0066 & 0.9025 \\
\hline & Disagree & 3 & 2.0 & & \\
\hline & Strongly Disagree & 3 & 2.0 & & \\
\hline & Strongly Agree & 60 & 39.5 & & \\
\hline Globalization in Ethiopla Increased & Agree & 72 & 47.4 & 1.7368 & 0.6783 \\
\hline & Neutral & 20 & 13.2 & & \\
\hline & Strongly Agree & 65 & 42.8 & & \\
\hline Globalization In Ethiopla Ignores Ine & Agree & 56 & 36.8 & 1.7763 & 0.7651 \\
\hline & Neutral & 31 & 20.4 & & \\
\hline & Strongly Agree & 77 & 50.7 & & \\
\hline Giobalization in Ethıopia enhanced & Agree & 60 & 39.5 & 1.5921 & 0.6647 \\
\hline & Neutral & 15 & 9.9 & & \\
\hline & Strongly Agree & 96 & 63.2 & & \\
\hline Giobalızatıon in Ethıopia enhanced & Agree & 52 & 34.2 & 1.3947 & 0.5417 \\
\hline & Neutral & 4 & 2.6 & & \\
\hline Globalization in Ethiopia forced cultural & Strongly Agree & 122 & 80.3 & & \\
\hline Globalization in Etniopla torced cuitural & Agree & 29 & 19.1 & 1.2039 & 0.4203 \\
\hline & Neutral & 1 & .7 & & \\
\hline Globalization in Ethiopia leads to lose its & Strongly Agree & 115 & 75.7 & & \\
\hline safe environment because of unsafe & Agree & 32 & 21.1 & 1.2763 & 0.51722 \\
\hline factories & Neutral & 5 & 3.3 & & \\
\hline Globalization in Ethiopia leads to increased & Strongly Agree & 108 & 71.1 & & \\
\hline deforestation in Ethiopia & Agree & 44 & 28.9 & 1.2895 & 0.45502 \\
\hline & Strongly Agree & 4 & 2.6 & & \\
\hline & Agree & 14 & 9.2 & & \\
\hline 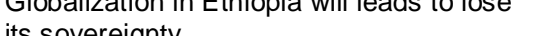 & Neutral & 67 & 44.1 & 3.5197 & 1.02272 \\
\hline & Disagree & 33 & 21.7 & & \\
\hline & Strongly Disagree & 34 & 22.4 & & \\
\hline
\end{tabular}

Table 5 to table 7 presents linear regression analysis for general views on globalizational impact on Ethiopia by using enter method. Table 5 presents model summary for the variables. The $R$ value is 0.80 is the values of the correlation coefficient between the predictors and the impact of globalization. $R^{2}$ value is 0.64 indicates predictors explains $64 \%$ variation on the dependent variable.

Table 6 presents ANOVA of general views on globalization in Ethiopia. The $F$ value is 11.634 at 0.000 significance level. The value of $F$ is statistically significant 
Karunakara Rao and Asfaw Temesgen

at a level of 0.05 or less, this suggests a linear relationship among the variables.

Table 7 presents beta coefficients and $t$ values for General perceptions on globalization. The beta variable is a measure of how strongly the independent variable influences the dependent variable. The size of the coefficient for each independent variable gives the size of the effect that variable is having on dependent variable, and the sign on the coefficient (positive or negative) gives the direction of the effect. The $t$ values indicate the variable statistical significance. In general a t value of 2 or higher indicates statistical significance.

Statements "Globalization in Ethiopia increased dependency on other countries" the B is 0.595 , and the Beta coefficient value is 0.579 at a significance level of 0.000 , "Globalization in Ethiopia helped to raise in income levels of the people" the B is 0.400 , and the Beta coefficient value is 0.451 , at a significance level of 0.000 , "Globalization helped Ethiopia to sell Ethiopian products across the countries" the B is 0.353 and the Beta coefficient value is 0.391 at a significance level of 0.000 , "Globalization provided Ethiopia with good infrastructural facilities" the B is 0.244 and the Beta coefficient value is 0.231 at a significance level of 0.007 ,"Globalization helped Ethiopia with access to hygiene living conditions" the $B$ is 0.103 and the Beta coefficient value is 0.119 at a significance level of 0.175 , "Globalization in Ethiopia helped to receive advanced technical know-how in the Ethiopia" the B is 0.124 and the Beta coefficient value is 0.115 at a significance level of 0.060 , "Globalization affected household and small industries in Ethiopia" the B is 0.074 and the Beta coefficient value is 0.096 at a significance level of 0.233 , "Globalization in Ethiopia helped to improve standard of living in the country" the B is 0.069 and the Beta coefficient value is 0.086 at a significance level of 0.178 , "Globalization helps to identify natural resources in Ethiopia" the B is 0.035 and the Beta coefficient value is 0.059 at a significance level of 0.472 , "Globalization in Ethiopia helped to receive qualitative education in the Ethiopia" the B is 0.054 and the Beta coefficient value is 0.054 at a significance level of 0.571 , "Globalization provided investments to different sectors in Ethiopia" the B is 0.035 and the Beta coefficient value is 0.054 at a significance level of 0.502 , "Globalization in Ethiopia enhanced corruption in the country" the B is 0.011 and the Beta coefficient value is 0.008 at a significance level of 0.916 are significant with positive beta coefficient values indicates existing lesser impact on dependent variable i.e. overall impact of globalization in Ethiopia, in descending order.

Statements "Globalization in Ethiopia enhanced employment opportunities in the country" the B is -0.274 , and the Beta coefficient value is -0.335 at a significance level of 0.000 , "Globalization in Ethiopia leads to lose its safe environment because of unsafe factories" the B is 0.334 , and the Beta coefficient value is -0.248 at a significance level of 0.020 , "Globalization in Ethiopia will leads to lose its sovereignty" the B is -0.135 , and the Beta coefficient value is -0.198 , at a significance level of 0.018 , "Globalization in Ethiopia ignores the concept of selfsufficiency" the B is -0.173 , and the Beta coefficient value is -0.190 at a significance level of 0.085 , Globalization helped Ethiopia with flow of more products from all over the world" the B is -0.156 , and the Beta coefficient value is

\section{Sci. Technol. Arts Res. J., Jan-March 2014, 3(1): 162-171}

-0.179 at a significance level of 0.085 , "Globalization in Ethiopia forced cultural change in the country" the B is 0.250 , and the Beta coefficient value is -0.151 at a significance level of 0.105 , "Globalization in Ethiopia leads to increased deforestation in Ethiopia" the B is -0.163 , and the Beta coefficient value is -0.106 , at a significance level of 0.188 , Globalization in Ethiopia enhanced inequalities in Ethiopian society" the B is -0.009 , and the Beta coefficient value is -0.008 , at a significance level of 0.926 - are insignificant with negative Beta values indicates existing higher impact on dependent variable i.e. overall impact of globalization in Ethiopia, in descending order.

Statements "Globalization in Ethiopia increased dependency on other countries" had $t$ value of 8.529, "Globalization in Ethiopia helped to raise in income levels of the people" had t value of 5.684, Globalization helped Ethiopia to sell Ethiopian products across the countries" had $t$ value of 4.085 and "globalization provided Ethiopia with good infrastructural facilities" had t value of 2.747 are significant $t$ values.

Table 8 presents profile of the sample cooperative organizations. 9.9 percent of the respondents working in Saving and Credit Cooperatives, 9.2 percent of the respondents working in Agricultural Cooperatives, 77.6 percent of the respondents working in Multipurpose cooperatives, and 3.3 percent of the respondents working in Other cooperatives i.e. consumer, rural electric supply etc. The mean for types of cooperatives is 3.5000 and standard deviation is 1.02292 . 12.5 percent of the sample cooperatives are established before year 1991, 8.6 percent of the sample cooperatives are established in between years 1992-1995, 34.9 percent of the sample cooperatives established in between years 1995-2000, 21.1 percent of the sample cooperatives established in between years 2001-2005, 19.7 percent of the sample cooperatives established in between years 2006-2010, and 3.3 percent of the sample cooperatives established in between 2010-2013. The mean for the year of establishment is 3.3684 and the standard deviation is 1.32567. 15.1 percent of the sample cooperatives had less than 100 members, 19.1 percent of the sample cooperatives had 100-200 members, 17.8 percent of the sample cooperatives had 201-300 members, 17.1 percent of the sample cooperatives had 301-400 members, 11.8 percent of the sample cooperatives had 401-500 members, and 19.1 percent of the sample cooperatives had more than 500 members. The mean is for member strength of sample cooperatives 3.4868 , and the standard deviation is 1.71471. 7.2 percent of the sample cooperatives having capital in between 5000-20000 ETB, 13.2 percent of the sample cooperatives having capital in between 20001-50000 ETB, 20.4 percent of the sample cooperatives having capital in between 50001-100000 ETB, 21.1 percent of the sample cooperatives having capital in between 100001-150000 ETB, 16.4 percent of the sample cooperatives having capital in between 150001-200000 ETB, 21.7 percent of the sample cooperatives having capital more than 200000 ETB. The mean for sample cooperatives capital is 3.9145 and standard deviation is 1.55663 .

Table 9 presents opinions of the respondents regarding globalization impact on Ethiopian cooperative organizations in Oromiya region. It presents the frequencies, mean opinions and the standard deviations. 
Table 5: Regression model summary for globalizational impact on Ethiopia.

\begin{tabular}{cccc}
\hline $\mathbf{R}$ & $\mathbf{R}$ Square & Adjusted R Square & Std. Error of the Estimate \\
\hline $0.800^{\mathrm{a}}$ & 0.640 & 0.585 & 0.44883 \\
\hline
\end{tabular}

Table 6: ANOVA for globalizational impact on Ethiopia.

\begin{tabular}{cccccc}
\hline & Sum of Squares & Df & Mean Square & F & Sig. \\
\hline Regression & 46.874 & 20 & 2.344 & 11.634 & $.000^{b}$ \\
Residual & 26.389 & 131 & .201 & & \\
\hline Total & $\mathbf{7 3 . 2 6 3}$ & $\mathbf{1 5 1}$ & & & \\
\hline
\end{tabular}

Table 7: Coefficients for globalizational impact on Ethiopia.

\begin{tabular}{|c|c|c|c|c|c|}
\hline \multirow[t]{2}{*}{ Model } & \multicolumn{2}{|c|}{$\begin{array}{l}\text { Unstandardized } \\
\text { Coefficients }\end{array}$} & \multirow{2}{*}{$\begin{array}{c}\begin{array}{c}\text { Standardized } \\
\text { Coefficients }\end{array} \\
\text { Beta }\end{array}$} & \multirow[t]{2}{*}{ t } & \multirow[t]{2}{*}{ Sig. } \\
\hline & B & Std. Error & & & \\
\hline (Constant) & 0.387 & 0.490 & & 0.789 & 0.431 \\
\hline Globalization helps to identify natural resources in Ethiopia & 0.035 & 0.049 & 0.059 & 0.721 & 0.472 \\
\hline Globalization provided investments to different sectors in Ethiopia & 0.035 & 0.052 & 0.054 & 0.674 & 0.502 \\
\hline $\begin{array}{l}\text { Globalization in Ethiopia helped to receive qualitative education in the } \\
\text { Ethiopia }\end{array}$ & 0.054 & 0.095 & 0.054 & 0.568 & 0.571 \\
\hline $\begin{array}{l}\text { Globalization in Ethiopia helped to receive advanced technical know- } \\
\text { how in the Ethiopia }\end{array}$ & 0.124 & 0.065 & 0.115 & 1.894 & 0.060 \\
\hline Globalization provided Ethiopia with good infrastructural facilities & 0.244 & 0.089 & 0.231 & 2.747 & 0.007 \\
\hline $\begin{array}{l}\text { Globalization in Ethiopia helped to improve standard of living in the } \\
\text { country }\end{array}$ & 0.069 & 0.051 & 0.086 & 1.355 & 0.178 \\
\hline Globalization in Ethiopia helped to raise in income levels of the people & 0.400 & 0.070 & 0.451 & 5.684 & 0.000 \\
\hline $\begin{array}{l}\text { Globalization in Ethiopia enhanced employment opportunities in the } \\
\text { country }\end{array}$ & -0.274 & 0.075 & -0.335 & -3.641 & 0.000 \\
\hline Globalization helped Ethiopia with access to hygiene living conditions & 0.103 & 0.075 & 0.119 & 1.365 & 0.175 \\
\hline $\begin{array}{l}\text { Globalization helped Ethiopia with flow of more products from all over } \\
\text { the world }\end{array}$ & -0.156 & 0.090 & -0.179 & -1.733 & 0.085 \\
\hline $\begin{array}{l}\text { Globalization helped Ethiopia to sell Ethiopian products across the } \\
\text { countries }\end{array}$ & 0.353 & 0.086 & 0.391 & 4.085 & 0.000 \\
\hline Globalization affected household and small industries in Ethiopia & 0.074 & 0.062 & 0.096 & 1.198 & 0.233 \\
\hline Globalization in Ethiopia increased dependency on other countries & 0.595 & 0.070 & 0.579 & 8.529 & 0.000 \\
\hline Globalization in Ethiopia ignores the concept of self-sufficiency & -0.173 & 0.100 & -0.190 & -1.735 & 0.085 \\
\hline Globalization in Ethiopia enhanced inequalities in Ethiopian society & -0.009 & 0.092 & -0.008 & -0.093 & 0.926 \\
\hline Globalization in Ethiopia enhanced corruption in the country & 0.011 & 0.102 & 0.008 & 0.106 & 0.916 \\
\hline Globalization in Ethiopia forced cultural change in the country & -0.250 & 0.153 & -0.151 & -1.635 & 0.105 \\
\hline $\begin{array}{l}\text { Globalization in Ethiopia leads to lose its safe environment because of } \\
\text { unsafe factories }\end{array}$ & -0 & 0 & 48 & -2.364 & 0.020 \\
\hline Globalization in Ethiopia leads to increased deforestation in Ethiopia & -0.163 & 0.123 & -0.106 & -1.324 & 0.188 \\
\hline Globalization in Ethiopia will leads to lose its sovereignty & -0.135 & 0.056 & -0.198 & -2.399 & 0.018 \\
\hline
\end{tabular}

Table 8: Profile of respondents cooperative organizations

\begin{tabular}{|c|c|c|c|c|c|}
\hline & & Frequency & Percent & Mean & SD \\
\hline \multirow{4}{*}{$\begin{array}{c}\text { Type of } \\
\text { cooperative }\end{array}$} & Saving and Credit cooperative & 15 & 9.9 & \multirow{4}{*}{3.5000} & \multirow{4}{*}{1.02292} \\
\hline & Agricultural Cooperative & 14 & 9.2 & & \\
\hline & Multipurpose Cooperative & 118 & 77.6 & & \\
\hline & Other & 5 & 3.3 & & \\
\hline \multirow{6}{*}{$\begin{array}{c}\text { Year of } \\
\text { establishment }\end{array}$} & Before 1991 & 19 & 12.5 & \multirow{6}{*}{3.3684} & \multirow{6}{*}{1.32567} \\
\hline & $1992-1995$ & 13 & 8.6 & & \\
\hline & $1996-2000$ & 53 & 34.9 & & \\
\hline & $2001-2005$ & 32 & 21.1 & & \\
\hline & $2006-2010$ & 30 & 19.7 & & \\
\hline & $2011-2014$ & 5 & 3.3 & & \\
\hline \multirow{6}{*}{$\begin{array}{l}\text { Members } \\
\text { strength }\end{array}$} & Less than 100 & 23 & 15.1 & \multirow{6}{*}{3.4868} & \multirow{6}{*}{1.71471} \\
\hline & $101-200$ & 29 & 19.1 & & \\
\hline & $201-300$ & 27 & 17.8 & & \\
\hline & $301-400$ & 26 & 17.1 & & \\
\hline & $401-500$ & 18 & 11.8 & & \\
\hline & Above 500 & 29 & 19.1 & & \\
\hline \multirow{6}{*}{ Capital } & 5000 ETB - 20000 ETB & 11 & 7.2 & \multirow{6}{*}{3.9145} & \multirow{6}{*}{1.55663} \\
\hline & 20001 ETB -50000 ETB & 20 & 13.2 & & \\
\hline & 50001 ETB - 100000 ETB & 31 & 20.4 & & \\
\hline & 100001 ETB - 150000 ETB & 32 & 21.1 & & \\
\hline & 150001ETB - 200000 ETB & 25 & 16.4 & & \\
\hline & Above 200000 ETB & 33 & 21.7 & & \\
\hline
\end{tabular}


Table 9: Respondents views on impact of globalization on Ethiopian cooperatives.

\begin{tabular}{|c|c|c|c|c|c|}
\hline & & Frequency & Percent & Mean & SD \\
\hline \multirow{3}{*}{$\begin{array}{l}\text { Globalization helped my cooperative organization to } \\
\text { follow } 7 \text { cooperative principles in its operation }\end{array}$} & Strongly Agree & 86 & 56.6 & \multirow{3}{*}{1.4737} & \multirow{3}{*}{0.5748} \\
\hline & Agree & 60 & 39.5 & & \\
\hline & Neutral & 6 & 3.9 & & \\
\hline \multirow{5}{*}{$\begin{array}{l}\text { Globalization helped my cooperative organization to } \\
\text { follow global standards in its operation }\end{array}$} & Strongly Agree & 12 & 7.9 & \multirow{5}{*}{2.3355} & \multirow{5}{*}{0.8836} \\
\hline & Agree & 101 & 66.4 & & \\
\hline & Neutral & 21 & 13.8 & & \\
\hline & Disagree & 12 & 7.9 & & \\
\hline & Strongly Disagree & 6 & 3.9 & & \\
\hline \multirow{5}{*}{$\begin{array}{l}\text { Globalization helped my cooperative organization to } \\
\text { adopt computerization }\end{array}$} & Strongly Agree & 6 & 3.9 & \multirow{5}{*}{3.9013} & \multirow{5}{*}{0.9612} \\
\hline & Agree & 6 & 3.9 & & \\
\hline & Neutral & 24 & 15.8 & & \\
\hline & Disagree & 77 & 50.7 & & \\
\hline & Strongly Disagree & 39 & 25.7 & & \\
\hline \multirow{5}{*}{$\begin{array}{l}\text { Globalization helped my cooperative organization to } \\
\text { adopt new technologies and practices }\end{array}$} & Strongly Agree & 30 & 19.7 & \multirow{5}{*}{2.5263} & \multirow{5}{*}{1.0418} \\
\hline & Agree & 39 & 25.7 & & \\
\hline & Neutral & 62 & 40.8 & & \\
\hline & Disagree & 15 & 9.9 & & \\
\hline & Strongly Disagree & 6 & 3.9 & & \\
\hline \multirow{5}{*}{$\begin{array}{l}\text { Globalization helped my cooperative organization to } \\
\text { access more finance from foreign investments }\end{array}$} & Strongly Agree & 12 & 7.9 & & \\
\hline & Agree & 15 & 9.9 & & \\
\hline & Neutral & 77 & 50.7 & 3.1184 & 0.9486 \\
\hline & Disagree & 39 & 25.7 & & \\
\hline & Strongly Disagree & 9 & 5.9 & & \\
\hline & Strongly Agree & 12 & 7.9 & & \\
\hline & Agree & 15 & 9.9 & & \\
\hline Globalization helped my cooperative organization to & Neutral & 62 & 40.8 & 3.2171 & 0.9828 \\
\hline access more inance irom roreign ald and aonatıons & Disagree & 54 & 35.5 & & \\
\hline & Strongly Disagree & 9 & 5.9 & & \\
\hline & Strongly Agree & 56 & 36.8 & & \\
\hline Globalıation helped my cooperatıve organıation's & Agree & 90 & 59.2 & 1.6711 & 0.5493 \\
\hline memoers to recerve qualitalve eaucalion & Neutral & 6 & 3.9 & & \\
\hline Globalization helned my connerative oroanization's & Strongly Agree & 63 & 41.4 & & \\
\hline Globalization nelped my cooperatıve organization's & Agree & 80 & 52.6 & 1.6447 & 0.5914 \\
\hline & Neutral & 9 & 5.9 & & \\
\hline & Strongly Agree & 3 & 2.0 & & \\
\hline Globalization holned my connerative oroanization's & Agree & 40 & 26.3 & & \\
\hline Globalization neiped my cooperative organization's & Neutral & 75 & 49.3 & 2.9408 & 0.7910 \\
\hline & Disagree & 31 & 20.4 & & \\
\hline & Strongly Disagree & 3 & 2.0 & & \\
\hline Because of globalization my cooperative & Strongly Agree & 72 & 47.4 & & \\
\hline organization's products facing lot of competition from & Agree & 68 & 44.7 & 1.6053 & 0.6320 \\
\hline multinationals & Neutral & 12 & 7.9 & & \\
\hline Because of globalization my cooperative & Strongly Agree & 104 & 68.4 & & \\
\hline organizations products losing demand - leads to & Agree & 45 & 29.6 & 1.3355 & 0.5140 \\
\hline elimination from the market & Neutral & 3 & 2.0 & & \\
\hline & Strongly Agree & 39 & 25.7 & & \\
\hline & Agree & 71 & 46.7 & & \\
\hline Because of globalization my cooperatıve & Neutral & 24 & 15.8 & 2.1776 & 1.0300 \\
\hline & Disagree & 12 & 7.9 & & \\
\hline & Strongly Disagree & 6 & 3.9 & & \\
\hline Because of globalization employees of cooperative & Neutral & 50 & 32.9 & & \\
\hline organizations are changing their jobs to multinational & Disagree & 51 & 33.6 & 4.0066 & 0.8178 \\
\hline corporations & Strongly Disagree & 51 & 33.6 & & \\
\hline Our cooperative organizations are facing problem of & Strongly Agree & 71 & 46.7 & & \\
\hline inadequate capital - hence facing competition from & Agree & 73 & 48.0 & 1.5855 & 0.5918 \\
\hline multinationals is challenging & Neutral & 8 & 5.3 & & \\
\hline Our cooperative organizations are facing problem of & Strongly Agree & 90 & 59.2 & & \\
\hline procuring raw material - hence facing competition & Agree & 56 & 36.8 & 1.4474 & 0.5730 \\
\hline from multinationals is challenging & Neutral & 6 & 3.9 & & \\
\hline Our cooperative organizations are facing marketing & Strongly Agree & 69 & 45.4 & & \\
\hline problems - hence facing competition from & Agree & 78 & 51.3 & 1.5789 & 0.5582 \\
\hline multinationals is challenging & Neutral & 5 & 3.3 & & \\
\hline Acquiring new technology and new methods involves & Strongly Agree & 121 & 79.6 & & \\
\hline huge costs - hence competing with multinationals is & Agree & 25 & 16.4 & 1.2434 & 0.5146 \\
\hline very hard & Neutral & 6 & 3.9 & & \\
\hline
\end{tabular}




\section{Karunakara Rao and Asfaw Temesgen}

Table 10 to table 12 presents linear regression analysis for globalization impact on Ethiopian cooperative organizations in Oromiya region. Table 10 presents the model summary for regression analysis. The $R$ value is 0.735 is the values of the correlation coefficient between the predictors and the impact of globalization on cooperatives. $R^{2}$ value is 0.540 indicates predictors explains 54.0 percent variation on the dependent variable. Table 11 presents Analysis of Variance of globalization impact on Ethiopian cooperatives. The $F$ value is 9.240 at 0.000 significance level. The value of $F$ is statistically significant at a level of 0.05 or less, this suggests a linear relationship among the variables. Table 12 presents beta coefficients and $t$ values for impact of globalization on Ethiopian cooperative organizations. Statements "Acquiring New Technology and New Methods Involves Huge Costs - Hence Competing with Multinationals Is Very hard" the B is 0.880 and the Beta coefficient is 0.441 at 0.000 significance level, "Because of Globalization Employees of Cooperative Organizations Are Changing Their Jobs to Multinational Corporations" the B is 0.285 and the Beta coefficient is 0.227 at 0.042 significance level, "Globalization Helped My Cooperative Organization's Products to Catch Global Demand" the B is 0.294 and the Beta coefficient is 0.226 at 0.003
Sci. Technol. Arts Res. J., Jan-March 2014, 3(1): 162-171

significance level, "Globalization Helped My Cooperative Organization's Members to Receive Qualitative Education" the B is 0.175 and the Beta coefficient is 0.093 at 0.423 significance level, "Globalization Helped My Cooperative Organization to Access More Finance from Foreign Aid and Donations" the B is 0.094 and the Beta coefficient is 0.090 at 0.605 significance level, "Globalization Helped My Cooperative Organization To Access More Finance From Foreign Investments" the B is 0.093 and the Beta coefficient is 0.086 at 0.597 significance level, "Globalization Helped My Cooperative Organization's Members to Receive Better Training Programs" the B is 0.123 and the Beta coefficient is 0.071 at 0.567 significance level, "Because Of Globalization My Cooperative Organization's Products Facing Lot of Competition from Multinationals" the B is 0.027 and Beta coefficient is 0.016 at 0.906 significance level, "My Cooperative Organizations Are Facing Problem of Inadequate Capital - Hence Facing Competition from Multinationals Is Challenging" the B is 0.006 and the Beta coefficient is 0.004 at 0.960 significance level are significant with positive beta coefficient values indicates existing lesser impact on dependent variable i.e. overall impact of globalization on Ethiopian cooperatives, in descending order.

Table 10: Regression model summary for globalizational impact on cooperatives.

\begin{tabular}{cccc}
\hline $\mathbf{R}$ & $\mathbf{R}$ Square & Adjusted R Square & Std. Error of the Estimate \\
\hline 0.735 & 0.540 & 0.481 & 0.7396
\end{tabular}

Table 11: ANOVA for globalizational impact on cooperatives.

\begin{tabular}{cccccc}
\hline & Sum of Squares & Df & Mean Square & F & Sig. \\
\hline Regression & 85.914 & 17 & 5.054 & 9.240 & 0.000 \\
Residual & 73.290 & 134 & 0.547 & & \\
\hline Total & $\mathbf{1 5 9 . 2 0 4}$ & $\mathbf{1 5 1}$ & & & \\
\hline
\end{tabular}

Table 12: Coefficient for globalizational impact on cooperatives.

\begin{tabular}{|c|c|c|c|c|c|}
\hline & \multicolumn{2}{|c|}{$\begin{array}{l}\text { Unstandardized } \\
\text { Coefficients }\end{array}$} & \multirow{2}{*}{$\begin{array}{c}\text { Standardized } \\
\text { Coefficients } \\
\text { Beta }\end{array}$} & \multirow[t]{2}{*}{$\begin{array}{ll}T \\
\end{array}$} & \multirow[t]{2}{*}{ Sig. } \\
\hline & B & Std. Error & & & \\
\hline (Constant) & 0.878 & 10.158 & & 0.759 & 0.449 \\
\hline $\begin{array}{l}\text { Globalization helped my cooperative organization to follow } 7 \\
\text { cooperative principles in its operation }\end{array}$ & -0.366 & 0.173 & -0.205 & -2.109 & 0.037 \\
\hline $\begin{array}{l}\text { Globalization helped my cooperative organization to follow global } \\
\text { standards in its operation }\end{array}$ & -0.108 & 0.108 & -0.093 & -1.000 & 0.319 \\
\hline $\begin{array}{l}\text { Globalization helped my cooperative organization to adopt } \\
\text { computerization }\end{array}$ & -0.068 & 0.102 & -0.064 & -0.665 & 0.507 \\
\hline $\begin{array}{l}\text { Globalization helped my cooperative organization to adopt new } \\
\text { technologies and practices }\end{array}$ & -0.100 & 0.120 & -0.101 & -0.827 & 0.409 \\
\hline $\begin{array}{l}\text { Globalization helped my cooperative organization to access more } \\
\text { finance from foreign investments }\end{array}$ & 0.093 & 0.176 & 0.086 & 0.529 & 0.597 \\
\hline $\begin{array}{l}\text { Globalization helped my cooperative organization to access more } \\
\text { finance from foreign aid and donations }\end{array}$ & 0.094 & 0.181 & 0.090 & 0.519 & 0.605 \\
\hline $\begin{array}{l}\text { Globalization helped my cooperative organization's members to } \\
\text { receive qualitative education }\end{array}$ & 0.175 & 0.217 & 0.093 & 0.804 & 0.423 \\
\hline $\begin{array}{l}\text { Globalization helped my cooperative organization's members to } \\
\text { receive better training programs }\end{array}$ & 0.123 & 0.214 & 0.071 & 0.574 & 0.567 \\
\hline $\begin{array}{l}\text { Globalization helped my cooperative organization's products to } \\
\text { catch global demand }\end{array}$ & 0.294 & 0.096 & 0.226 & 3.074 & 0.003 \\
\hline $\begin{array}{l}\text { Because of globalization my cooperative organization's products } \\
\text { facing lot of competition from multinationals }\end{array}$ & 0.027 & 0.224 & 0.016 & 0.118 & 0.906 \\
\hline $\begin{array}{l}\text { Because of globalization my cooperative organizations products } \\
\text { losing demand - leads to elimination from the market }\end{array}$ & 0.108 & 0.249 & 0.054 & 0.435 & 0.664 \\
\hline $\begin{array}{l}\text { Because of globalization my cooperative organizations are ignored } \\
\text { by the government }\end{array}$ & -0.303 & 0.066 & -0.303 & -4.580 & 0.000 \\
\hline $\begin{array}{l}\text { Because of globalization employees of cooperative organizations } \\
\text { are changing their jobs to multinational corporations }\end{array}$ & 0.285 & 0.139 & 0.227 & 2.050 & 0.042 \\
\hline $\begin{array}{l}\text { My cooperative organizations are facing problem of inadequate } \\
\text { capital - hence facing competition from multinationals is } \\
\text { challenging }\end{array}$ & 0.006 & 0.126 & 0.004 & 0.050 & 0.960 \\
\hline
\end{tabular}




\begin{tabular}{|c|c|c|c|c|c|}
\hline $\begin{array}{l}\text { My cooperative organizations are facing problem of procuring raw } \\
\text { material -hence facing competition from multinationals is } \\
\text { challenging }\end{array}$ & -0.472 & 0.133 & -0.263 & -3.552 & 0.001 \\
\hline $\begin{array}{l}\text { My cooperative organizations are facing marketing problems - } \\
\text { hence facing competition from multinationals is challenging }\end{array}$ & -0.116 & 0.136 & -0.063 & -0.848 & 0.398 \\
\hline $\begin{array}{l}\text { Acquiring new technology and new methods involves huge costs } \\
\text { hence competing with multinationals is very hard }\end{array}$ & 0.880 & 0.146 & 0.441 & 6.018 & 0.000 \\
\hline
\end{tabular}

Statements "Because Of Globalization My Cooperative Organizations Are ignored By the Government" the B is 0.303 and the Beta coefficient is -0.303 at 0.000 significance level, "My Cooperative Organizations Are Facing Problem of Procuring Raw material - Hence Facing Competition From Multinationals Is Challenging" the $B$ is -0.472 and Beta coefficient is -0.263 at .001 significance level, "Globalization Helped My Cooperative Organization to Follow 7 Cooperative Principles in Its Operation" the B is -0.366 and the Beta coefficient is 0.205 at 0.037 significance level, "Globalization Helped My Cooperative Organization to Adopt New Technologies and Practices" the B is -0.100 and the Beta coefficient is 0.101 at 0.409 significance level, "Globalization Helped My Cooperative Organization to Follow Global Standards in Its Operation" the B is -0.108 and the Beta coefficient is -0.093 at 0.319 significance level, "Globalization Helped My Cooperative Organization to Adopt Computerization" the $B$ is -0.068 and the Beta coefficient is -0.064 at 0.507 significance level, "My Cooperative Organizations Are Facing Marketing Problems - Hence Facing Competition from Multinationals Is Challenging" the $B$ is -0.116 and Beta coefficient is -0.063 at 0.398 significance level - are insignificant with negative Beta values indicates existing higher impact on dependent variable i.e. overall impact of globalization on Ethiopian cooperatives in descending order.

\section{CONCLUSIONS}

Ethiopia and Ethiopian cooperatives are impacted by the globalization in many aspects. Present research revealed Ethiopia and Ethiopian cooperatives are receiving mixed results from the globalization. Globalization in Ethiopia positively benefited Ethiopia with increased employment opportunities in the country, improvement in infrastructure facilities, flow of goods from all over the world, attracting foreign investments, dissemination of education and technology, upgrading in living conditions and standard of living and negatively impacted with environmental degradation, deforestation, cultural change, corruption, inequalities, over dependency on other countries are negative results of globalization to the Ethiopia. Globalization to the Ethiopian cooperatives positively benefited with adoption of global cooperative principles, global standards, new technologies and methods, attracting investments and donations from the external world and qualitative education and training programs and negatively impacted with competition from the multinationals, inadequate finance, marketing, production facilities, neglected by the own government.

\section{REFERENCES}

Bezabih Emana (2012). Cooperative Movement in Ethiopia, Workshop on perspectives for Cooperatives in Eastern Africa. October 2-3, 2012, Uganda.

Bezabih Emana (2009). Cooperatives: a path to economic and social empowerment in Ethiopia, International Labour Organization working paper no.9, ISBN: 9789221225621.

David J. Spielman (2007). Mobilizing Rural Institutions for Sustainable Livelihoods and Equitable Development a
Case Study of Farmer Cooperatives in Ethiopia, IFPRI Working Paper, Washington, DC: International Food Policy Research Institute.

Federal Cooperative Agency (2013). Cooperative: Annual Magazine 10(1).

Federal Negarit Gazeta of the FDRE (1998). Proclamation No.147/1998 - Cooperative Societies Proclamation.

Federal Negarit Gazeta of the FDRE (2002), Proclamation No.274/2002 Cooperative Societies Proclamation.

Federal Negarit Gazeta of the FDRE (2002). Proclamation No.402/2002 Cooperative Societies Proclamation.

Gashaw Tadesse Abate., Gian Nicola Francesconi and Kindie Getnet. (2012). impact of agricultural cooperatives on smallholders' technical efficiency: evidence from Ethiopia, Working Paper no. 50 / 13 Euricse Working Paper Series ISSN 2281-8235

Gian Nicola Francesconi and Nico Heerin (2010) "Ethiopian Agricultural Cooperatives in an Era of Global Commodity Exchange: Does Organizational Form Matter? Journal of African Economies 36: 1-25.

Globalization a brief overview, International Monetary Fund Issues Brief - Issue 02/08.

Karunakara Rao, R. (2013). Globalization and its impact on Ethiopia. The Business and Management Review, 3(4): 213-217. Proceedings of the International Conference on the Restructuring of the Global Economy (ROGE), London-UK 2013.

Kifle Tesfamariam Sebhatu (2012). Determinants of women's empowerment in cooperatives societies: survey evidence from south eastern Tigrai, Ethiopia. Continental Journal of Social Sciences 5(2): 45-53.

Oromiya Regional Cooperative Promotion Agency (2013). Annual report (unpublished).

Ruerd Ruben and Jorge Heras. (2012). Social Capital, Governance and Performance of Ethiopian Coffee Cooperatives. Annals of Public and Cooperative Economics 83(4) 463-484.

Tanguy Bernarda., Alemayehu Seyoum Taffesseb., Eleni Gabre-Madhina. (2008). Impact of cooperatives on smallholders' commercialization behavior: evidence from Ethiopia. Journal of Agricultural Economics 39: 147-161.

Teigist Lemma. (2008). Growth without structures: the cooperative movement in Ethiopia in Cooperating out of poverty the renaissance of the African cooperative movement, International Labour Organization and Word Bank institute.

Veerakumaran. (2007). Ethiopian Cooperative Movement-An Explorative Study, Mekelle, Ethiopia.

Wegenie (1989). The performance of cooperatives at micro and macro level and the problems of development of cooperatives in Ethiopia". M.A Thesis, AA University.

Woldegebrial Zeweld, Dayanandan, R., Arne Olav Oyhus. (2010). Women empowerment and environment rehabilitation though cooperatives in high lands of Ethiopia. International Journal of Management Research 24-34.

Yuka Kodama. (2009). The Effects of Fair Trade on Coffee Producers: A Case Study of Ethiopian Coffee Cooperatives. Proceedings of the 16th International Conference of Ethiopian Studies. 